International Journal of Agriculture, Environment and Bioresearch

Vol. 5, No. 04; 2020

ISSN: $2456-8643$

\title{
EFFECTS OF WEATHER PATTERN ON THE YIELD OF WHITE YAM (DIOSCOREAE ROTUNDATA) IN THE NORTHERN GUINEA SAVANNA ECOLOGICAL ZONE OF NIGERIA: THE CASE STUDY OF TARABA STATE
}

\author{
Mohammed Bakoji Yusuf ${ }^{1^{*}}$,Iraru Yusuf ${ }^{2}$, Umar Jauro Abba $^{3}$ and Mohammed Saleem Isa ${ }^{4}$ \\ ${ }^{134}$ Department of Geography, Faculty of Social \& Management Sciences, Taraba State University, Jalingo, Nigeria. \\ ${ }^{2}$ Office of the Surveyor General, Taraba State, Nigeria \\ https://doi.org/10.35410/IJAEB.2020.5527
}

\begin{abstract}
This research evaluated the effects of weather patterns on the yield of three selected white yam cultivars 'Yalzo', 'Jajetin' and 'Dan Anacha' in Ardo-kola LGA, Taraba State. The experiment was conducted during the 2016/2017 growing season along Sunkani - Bali highway opposite College of Agriculture Jalingo Taraba State. The experiment was carried out in Randomized Complete Block Designed (RCBD) using 3 replications. The meteorological data were collected from Taraba State University Jalingo, meteorological station throughout the growing season. Based on weather patterns during the cropping season, highest rainfall was recorded in the month of August with the total of $175 \mathrm{~mm}$ and decreases toward October. There is inverse relationship with rainfall and Maximum temperature, Minimum temperature and sunshine hours, while Relative Humidity showed a direct relationship with rainfall. Correlation result showed that, almost all the climatic elements correlates positively with (Tuber bulking) yam yields with relative humidity and soil temperature displaying highly positive correlation with yam yield at 0.01 probability level. Variation in yield of yam revealed that, there is a variation in the number of tuber per plant, tuber length, and total number of tuber per plot, weight of tuber per plot and tuber yield per hectare at $\mathrm{P}=0.05$, number of stem node at $\mathrm{P}=0.01$. It also revealed that cultivar 1 (Yalzo) proved to be the Cultivar that has the highest yield per plot and per hectare and responded well with the prevailing climatic condition of the Study Area, followed by jajetin (C2) and then by Dan onicha (C3). It is recommended that, cultivation of Yalzo should be promoted in the study area and early planting be encouraged by famers in order to improve the cultivation of yam in the study area.
\end{abstract}

Keywords: Weather, Yield, White Yam, Taraba State.

\section{INTRODUCTION}

Yams (Dioscorea SPP) are annual crops and form one of the major root crops grown in many part of the world and in the West African sub region in particular and Nigeria inclusive (Ayanlade,et al., 2010; Denis, 2014). The growth cycle of yam plant consists of four phases namely the root, vine, leaf and tuber (Adeniyan \& Owolade, 2012; Law-Ogbomo \& Remison, 2008). Each of these phases is very vital to yam yield (Enesi, et al., 2018; Sadauki \& Olanrewaju, 2012). Yam serves as a source of food to millions of people and livestock, and as a 
source of income to the growers (Bassey \& Akpan, 2015; Denis, 2014). According to (Awoniji \& Omonona, 2007; Bassey \& Akpan, 2015) yam is one of the most stable Nigeria foods for enhancing food security and achieving the Millennium Development Goals (MDG's). Reduction in the total yield of yam in a growing period can translates into decline in farmers' interest in the production of yam, and indirectly reduced farmers' welfare and psychological behavior the consequences of which are many and hazardous (Adewuyi, et al., 2014; Amit, et al., 2012; Demuyakor, et al., 2013).

Cultivation of yam is being affected by the impact of weather in many yams growing area particularly in the study area. Weather is the physical and environmental factor influencing crop growth. Optimal yield is possible when weather elements like rain, temperature, relative humidity and sunshine are favorable (Eruola, et al., 2012; Olanrewaju, 2008). Weather variability negatively translates into none optimal performance of the yam yield which in turn affect household food productions and consequently, hunger and food insecurity.

However, it has been observed that series of studies carried out on the impacts of weather on yam yield including those of Asala, \& Ebukiba, (2016), Emaziye, (2015), Enesi, et al., (2018), Eruola, et al., (2012), Timothy, \& Rasheed, (2017), Umoru, et al., (2015), were concentrated in the southern and eastern part of Nigeria with different geographical setting with the study region. In another dimension, previous studies had paid so much attention on the impacts of climate change on yam growgth, diseases and its management in Nigeria. While, knowledge on the major weather parameter affecting certain variety of yam yield will be useful to farmers in choosing suitable crop variety for a given area. Moreover, such knowledge will be of great significance to plants physiologist and agronomists in planning and maintaining yam production in order to increase its yield from the agro-climate variables in the study area and Nigeria at large.

Hence, there is dearth of information on the impacts of weather on yam yield in the study area. It is on this basis that this work seeks to examine the relationship between weather elements and yield parameters and identify the best cultivar(s) that is/are suitable to climatic conditions of the study area than to allow farmers to select the cultivars on their own.

\section{MATERIALS AND METHODS}

\subsection{Study Area}

The study area is located in the northern part of Taraba state latitudes $8^{0} 00^{\prime} \mathrm{N}$ to $9^{0} 40^{\prime} \mathrm{N}$ and longitudes $11^{0} 00^{\prime} \mathrm{E}$ to $12^{0} 00^{\prime} \mathrm{E}$ (Fig. 1). It has a total landmass of about $2,312 \mathrm{~km}^{2}$. The experimental site is located on latitude $08^{0} 53^{\prime} \mathrm{N}$ and longitude $011^{0} 18^{\prime} \mathrm{E}$ and lies about 240 meters above sea level (Field Survey 2016 GPS). The study area experience wet and dry climate (Oruonye \& Adebayo, 2015). Temperature is high all year round because of its latitudinal location. The mean maximum temperature is about $32.92^{\circ} \mathrm{C}$ and Minimum temperature is about $22.5^{\circ} \mathrm{C}$ and the Mean temperature is $27.7^{\circ} \mathrm{C}$. The highest air temperature is normally experienced in March and April with $31.84^{\circ} \mathrm{C}$. There is a distinct drop in temperature at the onset of rains due to the effects of cloudiness. The highest temperature is recorded in March and April. The 
minimum temperature value for the area can be as low as $18.7^{\circ} \mathrm{C}$ from December to January (Oruonye \& Adebayo, 2015).

Rainfall distribution pattern in the state shows a decrease from the south to the Northern part. The rainfall duration last between 167 to190 days in Northern part of the state ( Yusuf, et al., 2017). Ardo-kola has two distinct seasons, the rainy and dry season. The rainy season runs from the month of April through October, while the dry season commences in November and in February/March. The onset of rainfall, which is the time the place receives an accumulated amount of rainfall sufficient for growing of crops, commences between March to April. The onset of rainfall is occasionally heralded by dust/sand storm (Yusuf, et al., 2015). The average daily hours of bright sunshine are about 7-8 hours and the wind speed averaging about $76.1 \mathrm{~km} / \mathrm{h}$. The study area has a monthly mean sunshine hours of about 220 from January to April, but decrease to a mean value of 207 hours between June to September due to increase in cloudiness. The average sunshine hours for a year stand at about 2,750 hours approximately and evaporation is generally high due to high isolation (Girei, et al., 2014).

The soil types are characteristically of sandy loam and clay loam soil and suffer excessive internal drainage and intense leaching. The vegetation consists of open savannah woodland with small or medium size trees, and whose crowns are almost continuous, but through which light is able to penetrate widely. They have partial grass cover and the tree layer is virtually continuous (10-20m and 40-60 percent cover) (Girei et al., 2014). Farming is the major traditional occupation of the people. The farming system and farming practice are characteristically of the subsistence type and involve predominantly mixed or single cropping (Yusuf, 2014). Farm sizes vary with location, reflecting population density, accessibility to the farm and the personal preferences of the occupants. Yam, Guinea corns, and maize, are the major crops, cultivated by almost every farm family. Farming operations are generally labour-intensive and largely a reflection of traditional methods, using drudgery- enhancing primitive tools such as hoes, cutlasses, machetes, and axes, which have been passed from generation to generation (Ray \& Yusuf, 2011). 
International Journal of Agriculture, Environment and Bioresearch

Vol. 5, No. 04; 2020

ISSN: 2456-8643 
International Journal of Agriculture, Environment and Bioresearch

Vol. 5, No. 04; 2020

ISSN: 2456-8643

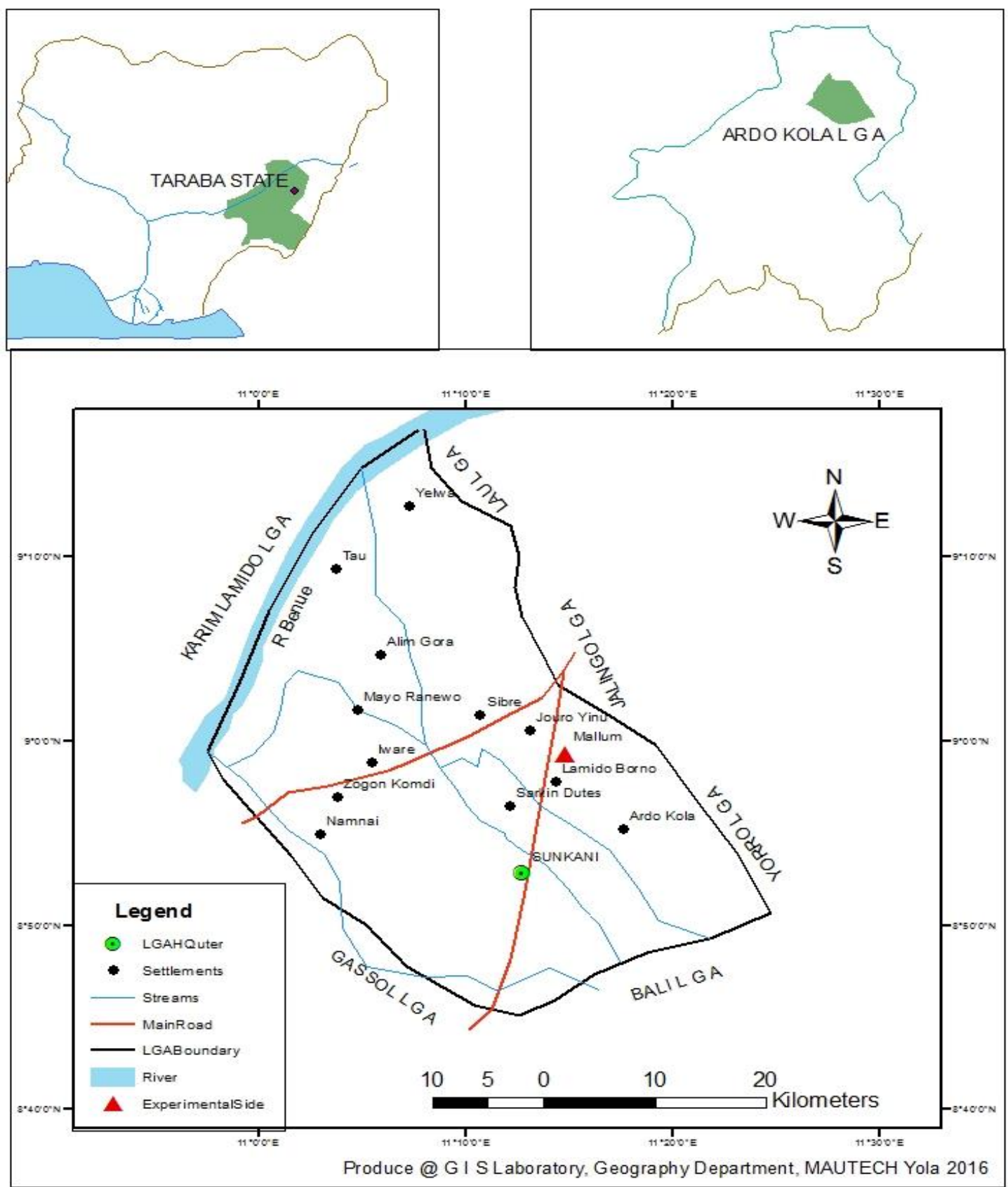

Figure 1; Map of the Study Area 


\section{International Journal of Agriculture, Environment and Bioresearch}

Vol. 5, No. 04; 2020

ISSN: $2456-8643$

\subsection{Methods}

The experimental site was established along Sunkani - Bali highway opposite collage of agriculture Jalingo Taraba state $\left(08^{0} 53^{\prime} \mathrm{N}\right.$ and $\left.011^{\circ} 18^{\prime} \mathrm{E}\right)$. The experimental site lies about 240 meters above sea level (Field Survey 2018 GPS). The block size was 20m x 20m and divided into 9 separate plots with each Cultivar replicated three times (i.e. 3 x $3=9$ ). That is, each cultivar has three plots. The number of yam mounds were 90 made manually using Africa hoe on $\left(19^{\text {th }}\right.$, November, 2018) this 90 mounds were divided into nine (9) separate plots for the three Cultivars. Each plot consists of 10 mounds and the mounds were $90 \mathrm{~cm}$ wide at the base and $60 \mathrm{~cm}$ high (i.e. sized of the mound). The mounds were spaced $1 \mathrm{~m}$ pathway within each plot. Path way of $1.5 \mathrm{~m}$ was allowed between plots. The outside margin was spaced $1 \mathrm{~m}$ away from the main plot. The mound tillage system was selected for the study because study has shown that mound tillage system improves the soil aeration and hydrothermal conditions for crops emergence, root development, crop growth and yield (Inyang, 2005).

The three local yam setts Cultivars were obtained from the local farmer in the study area. Whole yam setts weighing between 0.4 tolg for each cultivar were planted with one sett per mound. The three different yam cultivars were planted on 17th, December, 2016 and were mulched immediately after planting while staking was done after sprouting. Weed control was carried out using hand hoe three times throughout the cropping period.

Daily weather data including rainfall, maximum and minimum temperature, soil temperature, relative humidity, and sunshine hours were collected from Taraba State University Jalingo, meteorological station from December, 2016 - October, 2017. Data on yield parameters such as number of tubers per plant, tuber length and width per plant, tuber yield per plant, total number of tuber per plot, weight of tuber per plot and tuber yield $(\mathrm{kg} / \mathrm{ha})$ were measured in other to determine the effect of climate on the yield of yam. The yield parameters of the three yam cultivars were measured as thus;

i. Number of Tuber per Plant: The number of tuber per plant was obtained by counting the number of tuber per target plant in each plot. The total number was divided by three to obtain the mean number of tuber per plant. This was done after the plants were harvested.

ii. Tuber Length and Width: This was measured using a thread and meter rule. The thread was place on meter rule to obtain the length and width of plant in centimeters.

iii. Tuber Yield per Plant: The yield of tubers per plant was obtained by measuring the yield of all tubers harvested per plant using weight meters scale Model 1210. 
International Journal of Agriculture, Environment and Bioresearch

Vol. 5, No. 04; 2020

ISSN: $2456-8643$

iv. Number of Tuber per Plot: The number of tubers per plot was obtained by counting the total number of tuber in each plot. This was done after the tubers have been harvested.

v. Weight of Tuber per Plot: The weight of yam tubers per plot of land was obtained by measuring the weight of all tubers harvested per plot using weight meter scale Model 1210. This was done after the tubers have been harvested.

vi. Total Yield per Plot: Total yield of yam was obtained by collecting all the total yield of each plot after harvest and measured in $\mathrm{kg} / \mathrm{ha}$. The formula used for the calculation is Total yield $(\mathrm{kg} / \mathrm{ha})=\underline{\text { Tuber yield per plot }(\mathrm{kg}) \times 10,000 \mathrm{~m}^{2}}$

Plot size $\left(\mathrm{m}^{2}\right)$

Both descriptive and inferential statistics were used. The descriptive statistics involved the use of tables, percentage simple mean and graphs, while the inferential statistics are; Correlation and Analysis of Variance (ANOVA). The correlation analysis was used test the relationship of each weather variable with the yield of the three yam cultivars while, Analysis of Variance was employed to test the variations in the yield parameters of the three yam cultivars in relation to climatic condition of the study area. MINITAB statistical package was used for the study.

\section{RESULTS AND DISCUSSION}


Findings were discussed in three successes sections. The first section examines the climatic pattern of the study area during the growing to harvesting period. The second segment assessed the relationships between climatic factors and yield of yam and finally, the third discusses the variations in the yield of the three cultivars of yam in relation to climatic elements in the study area.

\subsection{Climatic Pattern of the Study Area during Growing to Harvesting Period}

Table 1 revealed the climatic pattern of the study area during the growing season. The climatic data were collected from Taraba state university Jalingo, meteorological station. The result shows that, the highest amount of rainfall was recorded in August with the total of $175 \mathrm{~mm}$ follow by September with $170.5 \mathrm{~mm}$ while the least was recorded in October $9 \mathrm{~mm}$. The rainy season runs from the month of April through early October.

An inverse relationship with rainfall and Maximum temperature, Minimum temperature and sunshine hours was recorded. This could be because of the effect of cloud produce by rain during the rainy season. Generally, all the three parameters decrease as rainfall increases. Similarly, an inverse relationship was noticed with rainfall and relative humidity in June as rainfall increases relative humidity also decreases, while in July as rainfall decreases relative humidity also increases. However, a direct relationship with rainfall and relative humidity in May and August (as rainfall increases relative humidity amount also increases) and in September and October (as rainfall decreases relative humidity also decreases) was recorded. 
International Journal of Agriculture, Environment and Bioresearch

Vol. 5, No. 04; 2020

ISSN: $2456-8643$

Table 1 Mean Climatic Data from Planting to Harvesting Period

\begin{tabular}{|c|c|c|c|c|c|}
\hline & Rainfall & $\begin{array}{l}\text { maximum } \\
\text { temperature }\end{array}$ & $\begin{array}{l}\text { minimum } \\
\text { temperature }\end{array}$ & $\begin{array}{l}\text { sunshine } \\
\text { hours }\end{array}$ & $\begin{array}{l}\text { relative } \\
\text { humidity }\end{array}$ \\
\hline $\mathrm{Dec} / 2016$ & - & 36.5 & 18.4 & 7.4 & 40.9 \\
\hline $\mathrm{Jan} / 2017$ & - & 33.8 & 18.2 & 7.7 & 41.5 \\
\hline Feb. & - & 37.39 & 18.03 & 8.5 & 54.04 \\
\hline March & - & 36.2 & 26.9 & 7.6 & 69.6 \\
\hline April & 19 & 34.4 & 26.03 & 6.4 & 75.6 \\
\hline May & 129 & 32.4 & 25.2 & 5.8 & 87.6 \\
\hline June & 156 & 31.1 & 24.5 & 5.1 & 80.2 \\
\hline July & 133.3 & 29.29 & 24.71 & 6.9 & 81.9 \\
\hline August & 175 & 29.25 & 24.4 & 5.11 & 89.6 \\
\hline September & 170.5 & 29.31 & 24.8 & 7.9 & 81.9 \\
\hline October & 9 & 33.2 & 25.7 & 9.2 & 74.7 \\
\hline Total & 865.8 & 432.78 & 299.27 & 92.18 & 906.34 \\
\hline Mean & & 33.29 & 23.02 & 7.09 & 69.72 \\
\hline
\end{tabular}


Vol. 5, No. 04; 2020

ISSN: $2456-8643$

Table 2 Yield Parameters for the three Yam Cultivars collected after Harvesting

\begin{tabular}{|c|c|c|c|c|c|c|c|}
\hline & $\begin{array}{l}\text { № of tuber } \\
\text { per plant }\end{array}$ & $\begin{array}{l}\text { Tuber length } \\
\text { per plant } \\
(\mathrm{cm})\end{array}$ & $\begin{array}{l}\text { Tuber width } \\
\text { per plant } \\
\text { (cm) }\end{array}$ & $\begin{array}{l}\text { Tuber yield } \\
\text { per plant } \\
\text { (kg) }\end{array}$ & $\begin{array}{l}\text { № of } \\
\text { tuber per } \\
\text { plot }\end{array}$ & $\begin{array}{l}\text { Weight of } \\
\text { tuber per } \\
\text { plot }(\mathrm{kg})\end{array}$ & $\begin{array}{l}\text { Tuber yield } \\
(\mathrm{kg} / \mathrm{ha})\end{array}$ \\
\hline C 1 REP. 1 & 3 & 36.6 & 34.2 & 7.4 & 32 & 84.5 & 33,800 \\
\hline REP.2 & 2 & 36.6 & 33.2 & 6.7 & 26 & 69.5 & 27,800 \\
\hline REP.3 & 3 & 33.1 & 25.6 & 7 & 29 & 78 & 31,200 \\
\hline Mean Value & & 35.4 & 31 & 7.0 & 29 & 77.3 & 30.93 \\
\hline C 2 REP.1 & 3 & 27.4 & 20.7 & 5.5 & 26 & 50.5 & 20,200 \\
\hline REP.2 & 2 & 32.3 & 30.3 & 5.4 & 23 & 46.5 & 18,600 \\
\hline REP.3 & 2 & 29.5 & 26.3 & 6.5 & 25 & 49 & 19,600 \\
\hline Mean Value & & 29.7 & 25.8 & 5.8 & 24.7 & 48.7 & 19.47 \\
\hline C 3 REP. 1 & 4 & 23.8 & 17.1 & 3.7 & 33 & 43.5 & 17,400 \\
\hline REP.2 & 3 & 29.5 & 32.3 & 6 & 29 & 42 & 16,800 \\
\hline REP.3 & 4 & 21.7 & 19.2 & 3.5 & 35 & 54 & 21,600 \\
\hline Mean Value & & 25 & 22.87 & 4.4 & 32.3 & 46.5 & 18.37 \\
\hline
\end{tabular}

$\mathrm{C} 1$ = Cultivar 1, C2 = Cultivar 2, C3 = Cultivar 3, Yalzo, Jajetin (wava) and Dan onicha as C1, $C 2$ and $C 3$ respectively. REP. Replication 1, 2, 3

Source: (Author's Field Study, 2017). 
The findings in Table 2 revealed that cultivar 1 (Yalzo) produced the highest mean values in all the Agronomic parameters measured followed by jajetin (C2) and then by Dan onicha (C3). This means that Yalzo responded well with the prevailing climatic condition of the Study Area.

\subsection{Relationship between climatic elements and yield of three yam cultivars}

Correlation between climatic elements and yield of yam was observed to see the significant of the relationship. The result of the correlation is presented in Table 3

Table 3 Correlations between climatic elements and yam yields

\begin{tabular}{|c|c|c|c|c|c|c|}
\hline & Rainfall & $\begin{array}{l}\text { Maximum } \\
\text { temperature }\end{array}$ & $\begin{array}{l}\text { minimum } \\
\text { temperature }\end{array}$ & $\begin{array}{l}\text { relative } \\
\text { humidity }\end{array}$ & $\begin{array}{l}\text { sunshine } \\
\text { hours }\end{array}$ & $\begin{array}{c}\text { Soil } \\
\text { temperature }\end{array}$ \\
\hline $\begin{array}{l}\text { Planting- } \\
\text { emergence }\end{array}$ & -0.524 & -0.524 & -0.524 & $0.745^{*}$ & $0.753^{*}$ & $0.705^{*}$ \\
\hline Vegetative & $0.957 * *$ & 0.506 & 0.532 & $0.877 * *$ & $0.741^{*}$ & 0.647 \\
\hline Flowering & $0.802 * *$ & 0.281 & $0.999 * *$ & $0.704 *$ & $0.967 * *$ & $0.724 *$ \\
\hline $\begin{array}{l}\text { Tuber } \\
\text { bulking }\end{array}$ & 0.608 & 0.641 & 0.108 & $0.982 * *$ & -0.189 & $0.912 * *$ \\
\hline
\end{tabular}

The correlation coefficients result displayed on Table 3 showed that almost all the climatic elements have a positive relationship with (Tuber bulking) yam yield. Rainfall, maximum and minimum temperatures showed positive correlation of $0.608,0.641$ and 0.108 respectively. Relative humidity and soil temperature displayed highly positive relationship with yam yield at 0.01 probability level. In general, only relative humidity and soil temperature showed highly positive significant relationship with yam at all the developmental stages. This implies that, relative humidity and soil temperature are very vital in all the developmental stages of yam in the study area, and thus any deficiency in it supply will affect yam yield negatively. 
Vol. 5, No. 04; 2020

ISSN: $2456-8643$

\subsection{Mean performance for yield parameters during the sampling period}

Results on yield parameters of the three selected Cultivars of yam were presented and discussed below.

\subsubsection{Numbers of Tuber per Plant}

The mean performance result in Table 4 showed significant differences at 0.05 probability level in numbers of Tuber per Plant for the three yam cultivars. The mean square values reveals that, $\mathrm{C} 3$ performed higher with 3.67 followed by $\mathrm{C} 1$ and lowest in $\mathrm{C} 2$ with 2.67 and 2.33 respectively. This finding support the conclusions earlier provided by Eruola et al., (2012); Sadauki \& Olanrewaju, (2012) that, the highest number of tubers per plants range from 2 to 3 .

\subsubsection{Tubers Length per Plant (cm)}

Variation in tubers length per plant as indicated in Table 4 showed a strong significant difference within the three selected cultivars of yam at 0.01 probability levels. This result is however at contrast with the finding earlier reported by Eruola et al., (2012) that, there is no significant differences found with tuber length per plant at $p>0.05$ of selected Cultivars of white yam planted at the Teaching and Research farm of University of Agriculture, Odeda Local Government Area of Ogun State in the 2007 and 2008 growing season. However, the mean performance of the three cultivars indicated that, $\mathrm{C} 1$ has the highest performance in terms of tubers length development followed by $\mathrm{C} 2$ and then $\mathrm{C} 3$ with $35.4 \mathrm{~cm}, 29.7 \mathrm{~cm}$ and $25 \mathrm{~cm}$ respectively (Table 2). This suggests that, $\mathrm{C} 1$ has produced tubers length sufficiently given the climatic condition than $\mathrm{C} 2$ and $\mathrm{C} 3$. However, the mean performance of the three cultivars has fallen within the optimum range of tubers length of $26.4 \mathrm{~cm}$ to $42.8 \mathrm{~cm}$ (Bassey \& Akpan, (2015)

\subsubsection{Tubers Width per Plant (cm)}

Table 4 showed the mean performance results in tuber width per plant which showed no significant difference in the three selected yam cultivars. However, the mean square performance value of $\mathrm{C} 1$ is larger than $\mathrm{C} 2$ and $\mathrm{C} 3 ; 31 \mathrm{~cm}, 25.77 \mathrm{~cm}$ and $22.87 \mathrm{~cm}$ respectively in relation to climatic condition of the study area (Table 2). This finding also fallen within the range of 31.7 $\mathrm{cm}$ to $32.7 \mathrm{~cm}$ reported by Bassey and Akpan, (2015), as the optimum circumferences of tubers width.

\subsubsection{Tubers Yield per Plant (kg)}

The mean performance result from Table 4, showed no significant difference in tuber yield per plant among the three cultivars. This result concurs with the finding earlier reported by (Eruola et al., 2012) where no significant difference with the number of tuber yield per plant at p> 0.05 of selected Cultivars of white yam was observed.

\subsubsection{Number of Tubers per Plot}

According to Table 4, there is highly significant diferences between the three selected Cultivars of yam in the study area for the number of tubers per plot at $\mathrm{P}=0.01$. The result also showed that, there is significant variation between $\mathrm{C} 2$ and $\mathrm{C} 3$ but showed slight variation between $\mathrm{C} 2$ and $\mathrm{C} 1$ and between $\mathrm{C} 1$ and $\mathrm{C} 3$ in which $\mathrm{C} 3$ recorded the highest number of tubers per plot followed by $\mathrm{C} 1$ and least by $\mathrm{C} 2$ in accordance with climatic condition of the study area. 


\subsubsection{Weight of Tubers per Plot $(\mathrm{kg})$}

Table 4 showed Variation in Weight of Tubers per Plot. The result reveals significant differences in weight of tubers between the three selected Cultivars of yam at 0.01 probability level. From the Table, C1 vary significantly from C2 and C3 but there is slight or no significant differences between $\mathrm{C} 2$ and $\mathrm{C} 3$. Similarly, Table also showed that, $\mathrm{C} 1$ has the highest weight of tuber followed by $\mathrm{C} 2$ and then $\mathrm{C} 3$ with $77.33 \mathrm{~kg}, 48.67 \mathrm{~kg}$ and $46.50 \mathrm{~kg}$ respectively. This result clearly showed that, $\mathrm{C} 1$ responded positively to weather variables in terms of tuber weight than $\mathrm{C} 2$ and $\mathrm{C} 3$.

\subsubsection{Tubers Yield per Hectare (kg)}

Results of tubers yield per hectare in Table 4, reveals highly significant difference at $\mathrm{P}=0.01$ of the three yam cultivars. The mean square values showed higher performance in $\mathrm{C} 1$ followed by C2 and lastly C3 with yield of $30,933.3 \mathrm{~kg}, 19,466.7 \mathrm{~kg}$ and $18,600 \mathrm{~kg}$ respectively Table 2. This result clearly showed that, $\mathrm{C} 1$ responded positively to climatic condition of the study area than $\mathrm{C} 2$ and $\mathrm{C} 3$ in terms of tuber yield per hectare and hence more suitable for planting in the study area

The result of variation in yield parameters among the three selected Cultivars of yam in Table 4, generally indicated that, tuber length per plant, number of tuber per plot, weight of tuber per plot, and tuber yield per hectare, showed highly significant difference at $\mathrm{P}=0.01$ while number of tuber per plant showed significant difference at $\mathrm{P}=0.05$ for the whole three selected Cultivars of yam. However, there were no significant differences observed in tuber width per plant and tuber yield per plant. 
International Journal of Agriculture, Environment and Bioresearch

Vol. 5, No. 04; 2020

ISSN: $2456-8643$

Table 4 Mean Performance for the Yield Parameters during Sampling Period (ANOVA)

\begin{tabular}{|cccccccc|}
\hline TRT & NoTPPLT & $\begin{array}{l}\text { TLPPLT } \\
(\mathrm{cm})\end{array}$ & $\begin{array}{l}\text { TWPPLT } \\
(\mathrm{cm})\end{array}$ & $\begin{array}{l}\text { TYPPLT } \\
(\mathrm{kg})\end{array}$ & NoTPPLOT & $\begin{array}{l}\text { WTPPLOT } \\
(\mathrm{kg})\end{array}$ & $\begin{array}{l}\text { TYPHA } \\
(\mathrm{kg})\end{array}$ \\
$\mathrm{C} 1$ & 2.67 & 35.43 & 31 & 7.03 & 29 & 77.33 & $30,933.3$ \\
$\mathrm{C} 2$ & 2.33 & 29.73 & 25.77 & 5.8 & 24.67 & 48.67 & $19,466.7$ \\
$\mathrm{C} 3$ & 3.67 & 25 & 22.87 & 4.4 & 32.33 & 46.50 & 18,600 \\
Mean & 2.89 & 30.05 & 26.55 & 5.74 & 28.67 & 57.50 & $23,000.01$ \\
LSD & 0.018 & 0.009 & 0.234 & 0.089 & 0.008 & 0.003 & 0.003 \\
& $*$ & $* *$ & NS & NS & $* *$ & $* *$ & $* *$ \\
\hline
\end{tabular}

TRT.$=$ Treatment, NoTPPLT $=$ Number of Tubers per Plant, TLPPLT $(\mathrm{cm})=$ Tubers length per plant, TWPPLT $(\mathrm{cm}) .=$ Tubers Width per Plant, TYPPLT $=$ Tuber Yield Per Plant, NoTPPLOT $=$ Number of Tuber Per Plot, WTPPLOT $=$ Weight of Tuber Per Plot, TYPHA. $=$ Tuber Yield per Hectare, C1, C2 and C3 = Cultivar 1, 2 and 3, NS = Not Significant, LSD = Least Significant Difference, $*=$ Significant at $\mathrm{P}=0.05, * *=$ Significant at $\mathrm{P}=0.01$.

Source: (Author's Field Study, 2017).

\section{CONCLUSION}

This study was conducted in a farm located along Sunkani - Bali highway opposite collage of agriculture Jalingo, Ardo-kola local government area of Taraba state. The study of the fundamentals of plant- climate relationship as advocated by Olaniran (1981) was adopted in plot design. The three selected white yam Cultivars were planted and replicated three times on each plot. The three selected Cultivars include: Yalzo, Jajetin (wava) and Dan onicha as C1, C2 and C3 respectively. Uniform cultural farm management practices was applied to the farm throughout the growing season. weather variables used in this study include, rainfall, maximum temperature, minimum temperature, soil temperature, sunshine and relatve humidity. Data on these weather elements were obtained from the meteorological station of Taraba State University Jalingo. Data on the crop yield parameters were collected on the farm. Correlation analysis was used to test the relationship between the weather elements and the yield parameters of yam while Analysis of variance (ANOVA) was used to determine the variation in the yield of yam in relation to climatic conditions of the study area. Based on weather patterns during the cropping season, highest rainfall was recorded in the month of August with the total of $175 \mathrm{~mm}$ and decreases toward October. There is inverse relationship with rainfall and Maximum temperature, Minimum temperature and sunshine hours, while Relative Humidity showed a direct relationship with rainfall. Correlation result showed that, almost all the climatic elements correlates positively with (Tuber bulking) yam yields with relative humidity and soil temperature displaying highly positive correlation with yam yield at 0.01 probability level. Variation in yield of yam revealed that, there is a variation in the number of tuber per plant, tuber length, and total number of tuber per plot, weight of tuber per plot and tuber yield per hectare at $\mathrm{P}=0.05$, number of stem node at 
Vol. 5, No. 04; 2020

ISSN: $2456-8643$

$\mathrm{P}=0.01$. It also revealed that cultivar 1 (Yalzo) proved to be the Cultivar that has the highest yield per plot and per hectare and responded well with the prevailing climatic condition of the Study Area, followed by jajetin (C2) and then by Dan onicha (C3). It is recommended that, cultivation of high yield cultivar Yalzo should be promoted for better and high yield in the study area. Farmers should be ecouraged to embark on early planting and staking of their yam vines. Similarly, seminars and workshops should be organized to give more orientation to farmers on the effects of climate on the growth and yield of yam.

\section{REFERENCE}

Adeniyan, O. N., \& Owolade, O. F. (2012). Comparative performance of improved white yam (Dioscorea rotundata) genotypes in the rainforest belt of South West Nigeria. . International Research Journal of Agricultural Science and Soil Science, 2(4), 127-132.

Adewuyi, S. A., Okojie, L. O., Folorunso, B., \& Bada, B. S. (2014). Effect of climate change on yam and cassava production in Oyo state, Nigeria: A co-integration model approach. . International Journal oF Agricultural Economics and Rural Development, , 6(1).

Amit, K. S., Thomas, G., Heiko, P., \& Frank, E. (2012). The Impacts of Climate change on Yam (Dioscorea alata yield in the savanna zone of West Africa. Journal of Agriculture, Ecosystems and Environment 15(3), 57-64.

Asala, S. W., \& Ebukiba, E. S. (2016). Profitability of yam production in Southern Guinea Savanna zone of Nigeria. Net Journal of Agricultural Science, 4(1), 9-14.

Awoniji, O. A., \& Omonona, B. T. (2007). Production efficiency in yam based enterprises in Ekiti State. Nigeria. Journal of Central European Agriculture., 7(4), 627-636.

Ayanlade, A., Odekunle, T. O., \& Orimoogunje, I. (2010). Impacts of climate variability on tuber crops in Guinea savanna part of Nigeria. A GIS approach, . Journal of Geography and Geology,, 2(1), 27-32.

Bassey, E. E., \& Akpan, U. S. (2015). Evaluation of Guinea White Yam Dioscorea rotundata poir). For yield and yield components in Nigeria,. American Journal of Experimental Agriculture,, 8(4), 216-223.

Demuyakor, B., Dukrog, T. m., \& Chikpah, S. K. (2013). Yam Germplasm in Ghana - A survey on variety identification and characterization of Dioscorea rotundata in Northern Region of Ghana. . International journal of Agronomy and plant production., 4(4), 719-726. . 4(4), 719-726. .

Denis, C. (2014). Yams (Dioscorea spp.) plant size hierarchy and yield variability: Emergency time is critical. European Journal of Agronomy 55, 100-107.

Emaziye, P. O. (2015). The influences of temperance and rainfall on the yield of maize, yam and cassava among rural household in Delta state, Nigeria. Journal of Biology, Agriculture and Health Care, 5(1).

Enesi, R., Oiza, Hauser, S., Lopez-Montez, A., \& Oluwole, O. (2018). Yam tuber and maize grain yield response to cropping system intensification in south-west Nigeria, . Archives of Agronomy and Soil Science, , 64(7), 953-966, DOI:910.1080/03650340.03652017.01404580.

Eruola, A. O., Bello, N. J., Ufoegbune, G. C., \& Makinde, A. A. (2012). Effect of variety selection on Growth, Development and Yield of White Yam in Southwestern Nigeria. 
Vol. 5, No. 04; 2020

ISSN: $2456-8643$

International Journal of Agriculture and Forestry,, 2(3), 101-104 Doi:110.5923/j.ijaf.20120203.20120204 .

Girei, A. A., Dire, B., Yuguda, R. M., \& Salihu, M. (2014). Analysis of productivity and technical efficiency of cassava production in Ardo kola and Gassol local government area of Taraba state. Nigeria. Agriculture, forestry and fisheries., 3(1), 1-5. Doi: 10. 11648/j.aff.20140301.20140311. .

Law-Ogbomo, K. E., \& Remison, S. U. (2008). Growth and Yield of White guinea yam (Dioscorea rotundata poir) Influenced by NPK fertilization on a forest site in Nigeria. Journal of Tropical Agricultural,, 46(1-2), 21-24.

Olanrewaju, R. M. (2008). Climate and the growth cycle of yam plant in the Guinea savanna ecological zone of Kwara state. Department of Geography, University of Ilorin. Journal of Meteorology \&Climate Science 7, 43-48.

Oruonye, E. D., \& Adebayo, A. A. (2015). An assessment of the level of farmer awareness and adaptation to climate change in northern Taraba state, Nigeria. Journal of social sciences research, 1(7), 79-85.

Ray, H. H., \& Yusuf, M. B. (2011). The Incidence of Soil Erosion in Zing local Government area of Taraba State, Nigeria. Ethiopian Journal of Environmental Studies and Management, 4(2), 9-18.

Sadauki, A. A., \& Olanrewaju, R. M. (2012). Effect of Climate on Yam tuberization in the Guinea Savanna Ecological Zone of Nigeria: The case study of Kwara state. Ethiopian Journal of Environmental Studies and Management, 5(2).

Timothy, D. A., \& Rasheed, A. B. (2017). Impact Of Climate On The Yield Of Major Tuber Cropsin Kwara State, Nigeria Global Journal Of Agricultural Sciences, 16, 61-65 DOI: http://dx.doi.org/10.4314/gjass.v4316i4311.4318.

Umoru, G. I., Barau, A. A., \& Attahiru, M. (2015). Relationship between Yam Yield and Climate Change Factors in Kwara state. . Journal of Agriculutral Science and Research $(J A S R), 5(1)$.

Yusuf, M. B. (2014). The Effect of Socio-Economic Characteristics of Peasant Farmers on Soil Erosion in Yorro Local Government Area of Taraba State, Nigeria. TSU Journal of Arts and Social Sciences, Jalingo,Taraba State., 3(1), 256-267.

Yusuf, M. B., B.M., F., \& Khairulmaini, O. S. (2015). Survey of Rill Erosion Characteristics of Small-scale Farmers' Crop Fields in the Northern Part of Taraba State, Nigeria. . International Journal of Tropical Agriculture, 33(4), 3305-3313.

Yusuf, M. B., B.M., F., \& Khairulmaini, O. S. (2017). Variation in Soil Physiochemical Properties at Different Land Use Sites in Northeastern Nigeria. International Journal of Applied and Physical Sciences, , 3(1), 26-34. DOI: https://dx.doi.org/10.20469/ijaps.20463.50005-20461.

Zakari, D. M., Mohammed, A. B., Medugu, N. I., \& Sandra, I. (2014). Impact of Climate change on Yam Production in Abuja, Nigeria. International Journal of Science, Environment and Technology,, 3(2), 458-472. 